\title{
RESPONSE OF NEWLY DEVELOPED SUNFLOWER HYBRIDS AND VARIETIES TO DOWIYY MILDEW DISEASE
}

\author{
Shirshikar, S.P.
}

Oilseeds Research Station, Latur-413 512 (M.S.) India

Received: June 26, 2007

Accepted: September 10, 2008

SUMMARY

Amongst the diseases on the cultivated sunflower (Helianthus annuus L.) in India, the downy mildew disease caused by the fungus Plasmopara halstedii (Farl.) Berl. \& De Toni is counted as important one. The disease is quite destructive as it is seed-borne and there are large chances for its fast spread to other sunflower growing localities. Use of resistant hybrids/varieties appears to be the only way to combat the disease.

During the kharif season of 2005-2006, 21 newly developed hybrids and 10 varieties were included in Initial Hybrid Trial (IHT), Advanced Hybrid Trial (AHT) and Initial/Advanced Variety Trial (I/AVT) within the framework of AllIndia Coordinated Program and were screened for downy mildew disease reaction. The hybrids/varieties were tested under high disease pressure in downy mildew infected plots at Oilseeds Research Station, Latur (M.S.), India. The data revealed that almost all newly developed varieties were susceptible to the disease. However, five hybrids, NSH-23, Sunbred-2077, NSSH-303, K-678 and MLSFH-93, were totally free from downy mildew incidence. Such hybrids can be exploited for commercial use.

Key words: sunflower, disease, screening, downy mildew, infected plot, reaction

\section{INTRODUCTION}

The cultivated sunflower (Helianthus annuus L.) is an important crop grown for edible oil. In India, sunflower has played an important role in Indian oilseeds scenario, registering a phenomenal acreage expansion and reaching a level of more than 2.1 million ha. Largest contributions to the expansion were made by the states of Karnataka, Maharashtra and Andhra Pradesh.

So far, more than 30 diseases have been reported on sunflower (Gulya et al., 1994), but fortunately only a dew of them are of economic significance in India.

* Corresponding author: Phone (office) (+ 91-02382) 245294, (home) (+ 91-02382) 226615; Fax (+91-02382) 245294 
Amongst these diseases, downy mildew caused by the fungus Plasmopara halstedii (Farl.) Berl. \& De Toni is important. Large-scale occurrence of this disease has been reported in many sunflower growing temperate tropical and subtropical countries of the world except Australia (Viranyi, 1990). Due of the seed-borne nature of the fungus, the disease has been rapidly distributed throughout the world by seed trade (Leepik, 1966). Cohen and Sackston, (1974) attributed the fast spread of the disease to the latent infection of the fungus.

In India, Ramnath et al. (1981) detected the presence of oospores on sunflower seeds imported from Bulgaria during early eighties. Later, Mayee and Patil (1988) reported its field occurrence at Oilseeds Research Station, Latur (M.S.) India. A major survey conducted during 1995-96 in major sunflower growing districts of Maharashtra state revealed that $36.37 \%$ of sunflower fields had downy mildew incidence with varying intensity up to $30 \%$ (Shirshikar, 1997). A downy-mildewinfected plot has been established at Latur Station, which facilitates effective screening of sunflower genotypes against this disease under high disease pressure condition. Based on extensive screening at Latur Station, Indian Council of Agricultural Research (ICAR) has released 8 sunflower hybrids/varieties having downy mildew resistance and good yield potential for commercial cultivation (Shirshikar, 2005a). Furthermore, use of Apron XL-35 E.S. (a metalaxyl fungicide) has been recommended for downy mildew disease management (Shirshikar, 2005b).

Recently, some newly developed sunflower hybrids and varieties included in All-India Coordinated Program were screened against downy mildew disease in the downy-mildew-infected plot at Latur Station The main object of this trial was to establish the downy mildew disease reaction of these hybrids/varieties in view of their further exploitation.

\section{MATERIAL AND METHODS}

A field trial was conducted in the downy-mildew-infected plot at Oilseeds Research Station, Latur, during kharif season of 2005-2006. Newly developed sunflower material, 21 hybrids and 10 varieties included in All-India Coordinated Program were screened against downy mildew under high disease pressure condition in the downy-mildew-infected plot. Out of the 21 hybrids, 15 hybrids were tested in initial hybrid trial (IHT) and 6 hybrids in advanced hybrids trial (AHT). Similarly, 10 new varieties were tested in initial / advanced variety trial (I/AVT). In order to have effective screening of sunflower hybrids/varieties, a radical inoculation technique (Patil et al., 1992) was followed. Accordingly, sunflower seeds of each test entry was soaked in tap water for 30 minutes and kept in rolled wet blotter paper individually for a period of three days to facilitate seed germination. When radicles attained a length of 2 to $3 \mathrm{~mm}$, the germinated seeds of each test entry were sprayed with downy mildew sporangial suspension individually and later sown in the infected plot. At the time of sowing, one row $(3 \mathrm{~m})$ of each test entry was alternated 
with a row of downy-mildew-susceptible variety Morden, which served as infector row. After germination, all test entries were sprayed daily with downy mildew fungal inoculum for a period of 15 days in order to create maximum disease pressure. Observations on downy mildew incidence on each test entry were recorded in twoweek intervals for 60 days. Mean disease incidence percentage was calculated for each test entry and the results are presented in Table 1.

Table 1: Reaction of some newly developed sunflower hybrids and varieties (tested within AllIndia Coordinated Program) against downy mildew disease at ORS, Latur (M.S.) India

\begin{tabular}{|c|c|c|c|c|}
\hline No. & Name of trial & $\begin{array}{l}\text { Total } \\
\text { entries }\end{array}$ & $\begin{array}{l}\text { Name of } \\
\text { test entry }\end{array}$ & $\begin{array}{c}\text { Downy mildew } \\
\text { disease incidence (\%) }\end{array}$ \\
\hline \multirow[t]{15}{*}{1} & Initial Hybrid Trial (IHT) & 15 & UAS (B)-05 & 1.47 \\
\hline & & & NSH-23 & 0.00 \\
\hline & & & LSFH-03-182 & 2.32 \\
\hline & & & LSFH-04-83273 & 32.53 \\
\hline & & & Narmada-45 & 25.00 \\
\hline & & & DRSH-306 & 38.09 \\
\hline & & & RSFH-130 & 22.14 \\
\hline & & & Sunbred Atul & 11.03 \\
\hline & & & NDSH-596 & 24.03 \\
\hline & & & CSFH-1002 & 22.33 \\
\hline & & & CSFH-1001 & 88.29 \\
\hline & & & JKSFH-238 & 83.33 \\
\hline & & & K-583 & 76.90 \\
\hline & & & DRSH-279 & 75.00 \\
\hline & & & DRSH-104 & 87.50 \\
\hline \multirow[t]{6}{*}{2} & Advanced Hybrid Trial (AHT) & 6 & KBSH-1 & 86.60 \\
\hline & & & Sunbred-2077 & 0.00 \\
\hline & & & NSSH-303 & 0.00 \\
\hline & & & K-678 & 0.00 \\
\hline & & & KBSH-44 & 72.22 \\
\hline & & & MLSFH-93 & 0.00 \\
\hline \multirow[t]{11}{*}{3} & Initial/Advanced Variety Trial (I/AVT) & 10 & LSF-158-338 & 29.95 \\
\hline & & & DRSF-113 & 85.00 \\
\hline & & & SRSF-118 & 48.95 \\
\hline & & & DRSF-119 & 73.61 \\
\hline & & & GAU SUF-12 & 63.45 \\
\hline & & & SS-2038 & 54.50 \\
\hline & & & LSFH-1-28 & 39.42 \\
\hline & & & DRSF-114 & 75.07 \\
\hline & & & DRSF-108 & 60.17 \\
\hline & & & LSF-IV-3-1 & 73.33 \\
\hline & & & Morden ( Check ) & 88.41 \\
\hline
\end{tabular}




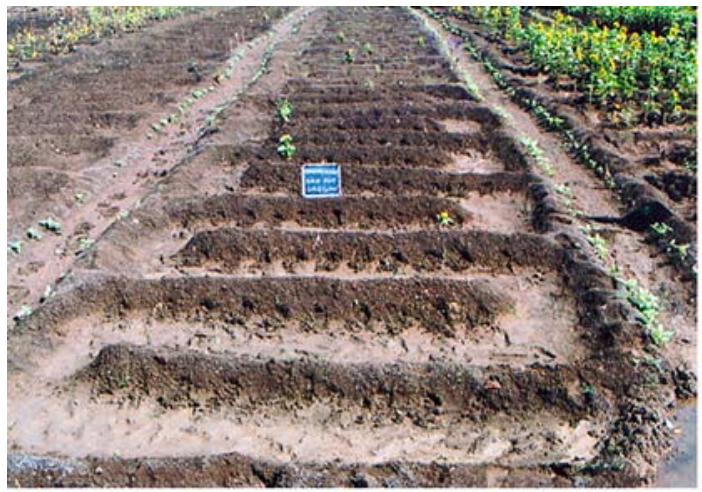

Figure 1: Downey mildew sick plot developed at ORS, Latur
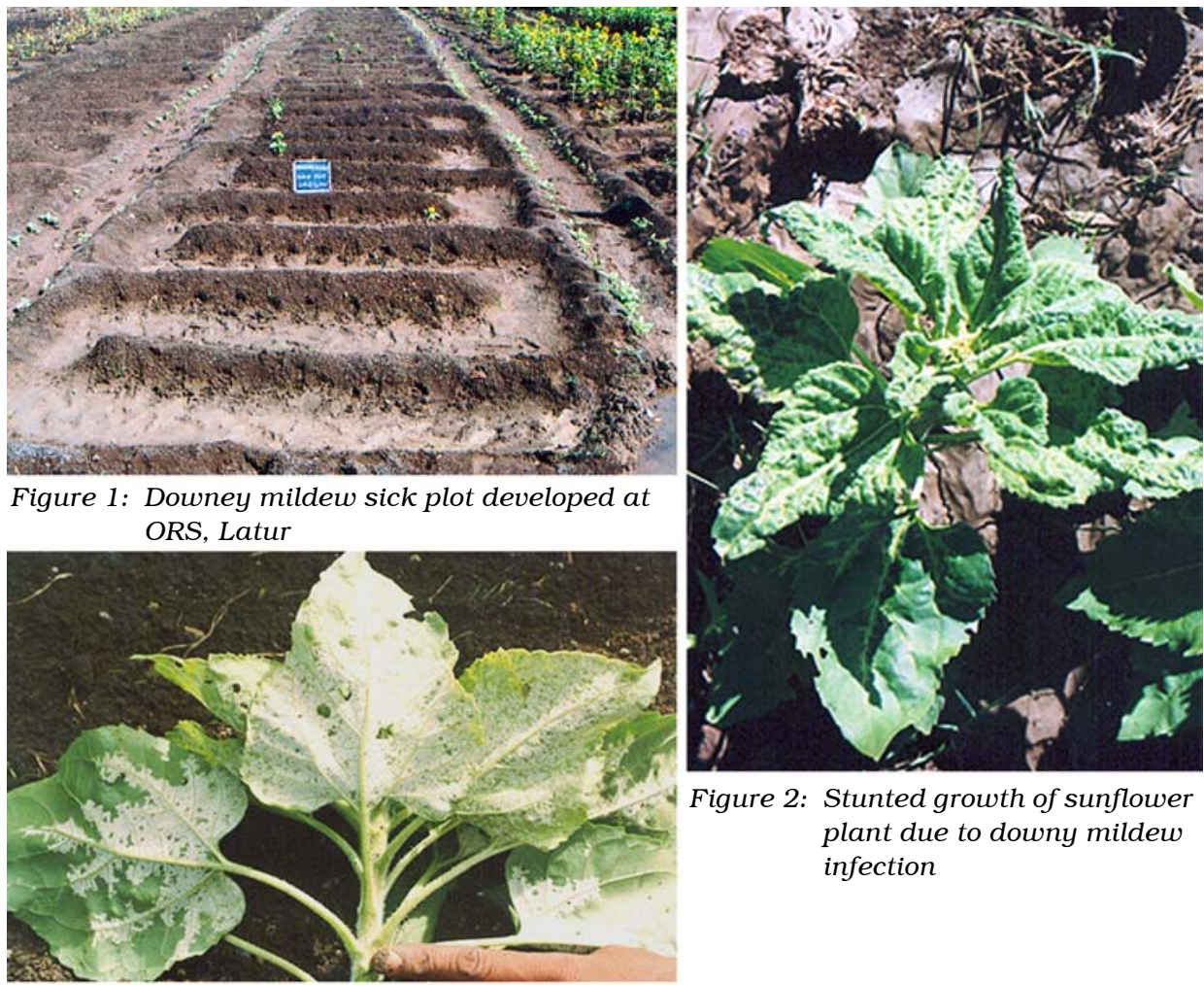

Figure 2: Stunted growth of sunflower plant due to downy mildew infection

Figure 3: Fungal growth of downy mildew on infected leaves

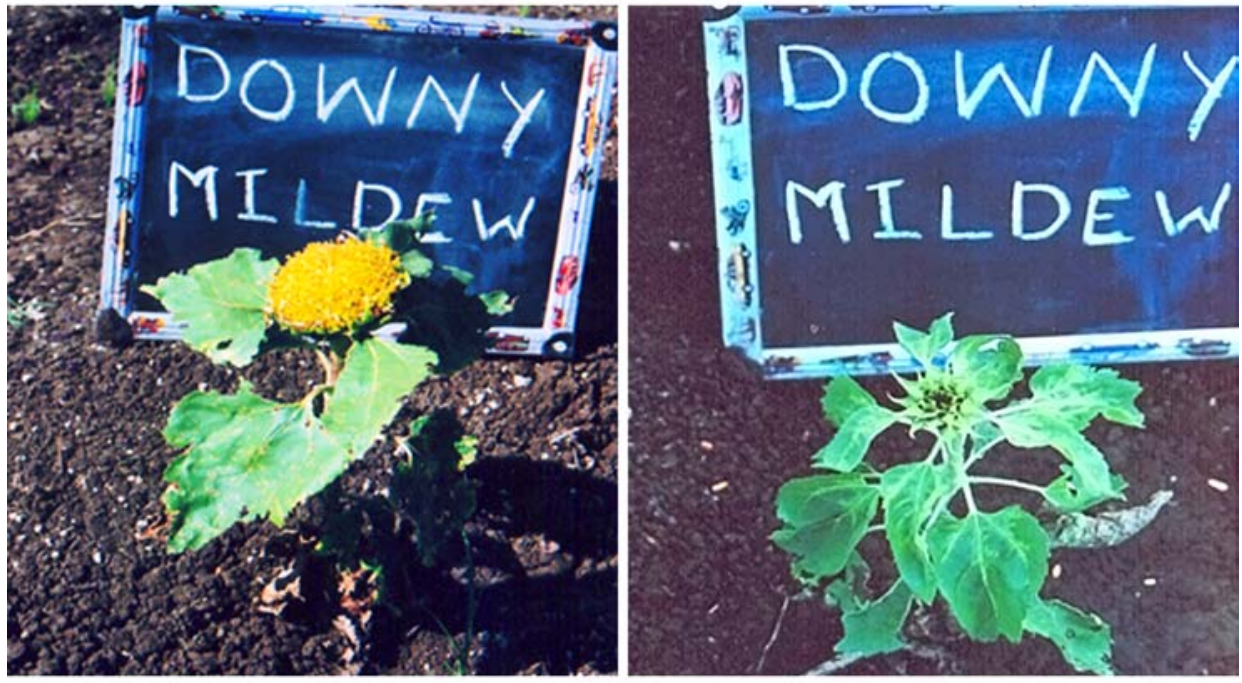

Figure 4: Sterile upright head without seeds Figure 5: Leaf chlorosis and stunting 


\section{RESULTS AND DISCUSSION}

The data presented in Table 1 show that the downy mildew incidence ranged from $1.47 \%$ to a maximum of $88.29 \%$ in the screening trial. Amongst the 15 newly developed sunflower hybrids included in Initial Hybrids Trial (IHT), only one hybrid, NSH-23, was found to be totally free from downy mildew incidence indicating its superiority over the other hybrids. The other hybrids had disease incidence in the range from 1.47 to a maximum of $88.29 \%$.

Out of six hybrids in the Advanced Hybrid Trial (AHT), four hybrids (Sunbred2077, NSSH-303, K-678 and MLSFH-93) were found to be free from downy mildew disease incidence. The other two hybrids had disease incidence in the range of 19.56 to a maximum of $86.60 \%$.

A total of 10 new sunflower varieties were tested in the Initial/Advanced Varietal Trial (I/AVT). The disease incidence ranged from 29.95 to $85.00 \%$ in this trial. However, none of the varieties was found to be disease free indicating their susceptibility to downy mildew disease. Similarly, the variety Morden which was used as downy mildew susceptible check, recorded a maximum disease incidence of $88.41 \%$.

Thus the screening results clearly indicated that, among the hybrids tested in the Initial Hybrid Trial (IHT), only one hybrid, NSH-23, exhibited downy mildew resistance. Four sunflower hybrids, Sunbred-2077, NSSH-303, K-678 and MLSFH93, included in the Advanced Hybrid Trial (AHT) showed resistant reaction against downy mildew disease and such hybrids can be exploited commercially. None of the varieties tested in the Initial/Advanced Varietal Trial (I/AVT) were found to be resistant to this disease. Apart from the hybrids mentioned above, two hybrids from the Initial Hybrid Trial (IHT) group, UAS-B-05 and LSFH-3-3182, recorded the lowest downy mildew disease incidences of 1.47 and $2.32 \%$, respectively, and these two hybrids, which may be considered as resistant, can be utilized in downy mildew endemic areas in addition to the above hybrids.

\section{ACKNOWLEDGEMENT}

The author is grateful to Dr. S.S. Kadam, Hon. Vice-Chancellor, MAU, Parbhani (M.S.), and Dr. D.M. Hedge, Project Director, DOR Hyderabad, India, for their encouragement and support.

\section{REFERENCES}

Cohen, V. and Sackston, W.E., 1974. Seed infection and latent infection of sunflower by $P$. halstedii. Canad. J. Bot. 52: 231-238.

Leepik, E.E., 1966. Origin and specialization of Plasmopara halstedii compels of the Compositae. FAO Plant. Prot. Bull. 14: 172.

Patil, M.A., Mayee, C.D. and Phad, H.B., 1992. Sunflower downy mildew. Information Bulletin, Oilseeds Research Station (MAU), Latur. pp. 76. 
Ramnath, A.K., Lambat, B.N., Mukewar and Indra Rani, 1981. Interceptions of pathogenic fungi on imported seed and planting material. Indian Phytopath. 34: 282-286.

Shirshikar, S.P., 1997. Survey of sunflower downy mildew disease in Marathwada region. J. Maharashtra Agric. Univ. 22(1): 135-136.

Shirshikar, S.P., 2005(a). Present status of sunflower downy mildew disease in India. Helia 28(43): 153-158.

Shirshikar, S.P., 2005(b). Control of downy mildew in sunflower with a new metalaxyl formulation (Apron XL-35 E.S.). Helia 26(39): 109-116.

Viranyi, F., 1990. Downy mildew of sunflower. In: Plant Diseases of International Importance (Eds. Chuge et al. 1980). Prentice Hall, Inglewood Cliff, New Jersey. 363: 328-340.

\title{
RESPUESTA DE HÍBRIDOS Y VARIEDADES DE GIRASOL RECIENTEMENTE DESARROLLADOS FRENTE AL DOWNY MILDEW
}

\author{
RESUMEN
}

Entre las enfermedades del girasol cultivado (Helianthus annuus L.) en India, el downy mildew provocado por el hongo Plasmopara halstedii (Farl.) Berl. \& De Toni es una de las más relevantes. La enfermedad es una de las más destructivas ya que ataca a la semilla y presenta muchas posibilidades de una expansión rápida a otras regiones girasoleras. El uso de variedades e híbridos resistentes podría ser la única manera de combatir la enfermedad.

Durante la estación Kharif 2005/2006, 21 híbridos recientemente desarrollados y 10 variedades incluidas en el programa All India dentro de los ensayos Inicial de Híbridos (IHT), Avanzado de Híbridos (AHT) e Inicial/Avanzado de Variedades (I/AVT) se evaluaron por su reacción frente a downy mildew. Todos estos híbridos/variedades se evaluaron bajo una alta presión de downy mildew en un infectario desarrollado en la Oilseeds Research Station, Latur (M.S.), India. Los datos revelaron que casi todas las variedades desarrolladas recientemente fueron susceptibles a esta enfermedad. Sin embargo, 5 híbridos (NSH-23, Sunbred-2077, NSSH-303, K-678 y MLSFH-93) no presentaron síntomas de downy mildew. Estos híbridos pueden explotarse para su uso comercial.

\section{RÉACTION À LA ROUILLE DES HYBRIDES ET DES SORTES DE TOURNESOL NOUVELLEMENT CRÉÉS}

RÉSUMÉ

Parmi les maladies du tournesol cultivé (Helianthus annuus L.) en Inde, le mildiou causé par Plasmopara halstedii (Farl.) Berl. et De Toni est des plus importantes. La maladie est diffusée par les semences et peut se diffuser très rapidement à d'autres zones de culture. L'utilisation d'hybrides ou de variétés résistantes pourrait constituer la seule méthode efficace de lute contre la maladie.

Au cours de la saison Kharif 2005-2006, 21 hybrides récemment développés et 10 variétés ont participé au réseau coordonné pan-indien au sein du protocole "Initial Hybrid trial" (IHT), "Advanced Hybrid trial" (AHT) and "Initial/Advanced varietal trial” (I/AVT) et ont été testés pour leur comportement vis-à-vis du mildiou. Tous les hybrides ou variétés ont été testés sous une forte pression pathogène dans des parcelles infectées à la Station de Recherche sur 
les Oléagineux de Latur (M.S.) Inde. Les données montrent que la grande majorité des hybrides récemment développés sont sensibles à cette maladie. Touetfois, cinq hybrides - NSH-23, Sunbred-2077, NSSH-303, K-678 et MLSFH-93 - ont été totalement indemnes de maladie. De tels hybrides peuvent être exploités commercialement. 
